\title{
Feijão-caupi: alternativa sustentável para os sistemas produtivos
}

Carlos Henrique Madeiros Castelletti, Antonio Felix da Costa

O feijão-caupi, também conhecido como feijão-macassar ou feijão-de-corda, vem adquirindo, nos últimos anos, maior expressão econômica, devido, basicamente, à busca da população por alimentos saudáveis e também à ampliação da área de sua produção, que corresponde a dois terços da produção de feijão do Nordeste e a um terço da produção nacional. Em virtude da importância da cultura do feijão-caupi, da sua adaptação a climas adversos - como a seca e as temperaturas elevadas - e das suas qualidades nutracêuticas, ampliou-se a área plantada na última década. Os dados de 2011 indicam que foi colhida, em aproximadamente 1,6 milhão de hectares, uma produção de 822 mil toneladas. A maior produção concentra-se na Região Nordeste, com $84 \%$ da área plantada e $68 \%$ da produção nacional, o que gerou, nos últimos cinco anos, 1,2 milhão de empregos diretos. Esses números colocam o Brasil como o terceiro maior produtor mundial do grão, atrás da Nigéria e do Níger.

Apesar de a maior parte da produção ainda ser oriunda da agricultura familiar, percebe-se certo interesse dos grandes produtores, que detêm maior poder aquisitivo e acesso a modernas tecnologias, o que contribui para a expansão das fronteiras agrícolas das Regiões Norte e Nordeste, seus principais produtores, para a Região Centro-Oeste.

Este maior interesse pela cultura do feijão-caupi trouxe a oportunidade de realizar periodicamente um congresso nacional, que reúna pesquisadores, produtores, alunos e interessados pela cultura. Neste ano, o Congresso Nacional de Feijão-Caupi - CONAC - foi realizado em Recife, Pernambuco, nos dias 22 a 24 de abril. Em sua terceira edição e com o tema 'Feijão-Caupi como alternativa sustentável para os sistemas produtivos familiares e empresariais', o congresso teve como objetivo intercambiar experiências e proporcionar informações atualizadas à comunidade acadêmica, aos produtores rurais, aos exportadores, aos consumidores e a todos aqueles que produzem ou que, de alguma forma, estão ligados à cultura do feijão-caupi, fortalecendo cada vez mais os elos dessa cadeia.

Participaram do evento aproximadamente 350 pessoas, entre pesquisadores, estudantes de Pós-Graduação e Graduação, extensionistas, técnicos agrícolas e empresários de diversos setores do agronegócio, comtemplando 25 Estados brasileiros - excetuando-se Rondônia e Espírito Santo, com mais de 70 instituições e empresas brasileiras representadas. Durante o congresso, 30 palestrantes nacionais abordaram as pesquisas realizadas nas áreas de exigências nutricionais, doenças, ervas daninhas, fixação biológica de nitrogênio, recursos genéticos, cultivares, melhoramento, biotecnologia, biofortificação e processamento, abrangendo toda a cadeia produtiva do feijão-caupi.

Além dos palestrantes nacionais, participaram do evento o Dr. Bir Bahadur Singh, da G.B. Plant University of Agriculture and Technology (Índia), o Dr. Michael Paul Timko, da Universidade da Vírginia (EUA), o Dr. Christian Fatokun, do International Institute of Tropical Agriculture (Nigéria) e o Dr. Mathias Fosu, do Savanna Agricultural Research Institute (Gana).

Em comemoração ao evento, realizado pelo Instituto Agronômico de Pernambuco (IPA), publicamos nesta edição da PAP um artigo em formato de nota científica, apresentando as pesquisas com a cultivar Miranda IPA 207. Intitulado 'Miranda IPA 207, Nova Cultivar de Feijão-Caupi para o Nordeste Brasileiro', os autores demonstram as vantagens desta nova variedade e sua adaptação às condições climáticas do Nordeste brasileiro. Com porte 
semiprostrado, a variedade possui ciclo médio da semeadura à floração de 40 a 45 dias, e ciclo médio da semeadura à maturação de colheita de 63 a 68 dias.

A Miranda IPA 207 é a mais nova dentre as mais de 21 variedades lançadas pelo Programa de Melhoramento de Feijão do IPA, que engloba o feijão comum e o feijão-macassar, e vem trabalhando há mais de 40 anos com a cultura do feijão-caupi, tendo sido lançadas, nesse período, sete variedades da cultura.

O nome da variedade é uma homenagem in memoriam ao Doutor Paulo Miranda, que foi, por mais de 30 anos, o grande melhorista de feijão do IPA, tendo sido responsável pela grande maioria das variedades lançadas. Grande geneticista, teve o merecido reconhecimento dos seus colegas nacionais e do Centro Internacional de Agricultura Tropical (CIAT). Algumas de suas variedades foram levadas pelo CIAT a países da América do Sul e da África, competindo em condições de igualdade com outras variedades, quando se destacaram por sua excelente produtividade e por sua resistência a doenças. No início da década de 1980, uma de suas variedades representava 95\% da área plantada com feijão em Irecê, na Bahia, então maior centro produtor dessa cultura no Nordeste.

Cerca de nove Estados brasileiros plantaram variedades IPA, inclusive São Paulo e Minas Gerais. Pela qualidade de suas pesquisas, pelo nível de produtividade alcançado, pelos diversos artigos publicados e pelo seu alto conhecimento naquilo que fazia, o Doutor Paulo Miranda recebeu o Prêmio Frederico Menezes da Veiga, a mais alta distinção dada pela Embrapa àqueles que se destacam na pesquisa científica relacionada à agropecuária no Brasil.

Ao Doutor Paulo Miranda, as homenagens da Revista Agropecuária Pernambucana. 